UDC 616.314-002: 613: 646

DOI: $10.21668 /$ health.risk/2017.4.10.eng

\title{
FACTORS CAUSING RISKS OF CARIES EVOLVEMENT IN DENTAL SOLID TISSUES UNDER ACCLIMATIZATION
}

\section{R.S. Rakhmanov, M.Kh. Alikberov, Z.A. Omarova}

Nizhegorodskiy Scientific Research Institute for Hygiene and Occupational Pathology, 20 Semashko Str., Nizhniy Novgorod, 603950, Russian Federation

We analyzed parameters characterizing mineral balance in a body and dental state in two groups of healthy men ( $n=15$ in each, aged $34.7 \pm 0.6)$ in hot and humid marine climate conditions; one group was made of people undergoing acclimatization, the second one consisted of local population.

We assessed working conditions and their category, and metrological data with determining environmental thermal load (ETL-index).

Both groups worked outdoors; their labor had IIb category; they had to work overtime and under increased psychoemotional loads; their working conditions differed as per nutrition and accommodation. When people from both groups had to work beyond their permanent location, their nutrition was represented by individual rations.

Labor hardness was assessed as 3.2; labor intensity, as 3.2. Daytime temperature reached $30,0{ }^{\circ} \mathrm{C}$, relative air humidity was $77.3 \pm 2.6 \%$, wind speed was $4.3 \pm 0.3 \mathrm{~m} / \mathrm{sec}$. Microclimate was assessed as having 3.1 hazard category. Overall, working conditions were assessed as hazardous (3.3 hazard category).

Electrolyte balance in a body was violated and it was proved by ower contents of $\mathrm{K}$, $\mathrm{Na}$, and $\mathrm{Cl}$ in blood serum; it was more apparent in people who were undergoing acclimatization. $70.0 \%$ of local people had Ca contents in blood serum lower than the physiological standard. Lower Ca and increased P contents in blood serum were also detected in those undergoing acclimatization which could be evidence that Ca was washed out of a body and greater risk of dental caries occurred. As per observation dynamics we detected the following processes in people undergoing acclimatization: $p H$ saliva and its mineralizing function shifting to acidity, salivation rate, and lower enamel resistance; they proved there was a growth in dental solid tissues demineralization. These parameters corresponded to those detected in local population. It calls for primary prevention activities aimed at fighting caries of dental solid tissues.

Key words: hot and humid marine climate, acclimatization, minerals, dental state, blood serum, risk, dental caries.

World practice has proved that prevention programs implementation leads to a drastic decrease in caries and teeth losses; prevention techniques are 20 times cheaper than treatment of already existing dental diseases $[5,19]$. Over the last three decades prevention programs implementation has resulted in decrease in caries prevalence in many regions all over the world and in all age groups. However, this trend hasn't occurred in all the social groups to the same extent: the disease risk turned out to be higher among population with low social-economic status (a substantial

(C) Rakhmanov R.S., Alikberov M.Kh., Omarova Z.A., 2017

Rofail' S. Rakhmanov - Doctor of Medical Sciences, Professor, Director (e-mail: raf53@mail.ru; tel.: +7 (831) 419-61-94).

Murat Kh. Alikberov - Junior Researcher at Laboratory for Assessing Actual Nutrition of Working Population (e-mail: recept@nniigp.ru; tel.: +7 (831) 419-61-94).

Zul'mira A. Omarova - A physician at Clinical-Diagnostic Laboratory (e-mail: recept@nniigp.ru; tel.: +7 (831) 419-61-94). 
growth was observed from 1990 to 2013) $[9,12,16-18]$.

One of the most important concepts underlying caries prevention is a fact that the carious process is simultaneously dynamic and reversible $[11,14]$. It happens due to demineralization and remineralization. Demineralization occurs when dental deposit acids on a tooth surface wash $\mathrm{Ca}$ ions and phosphate-ions out of enamel hydroxyapatites and it results in mineral substances losses out of teeth tissues. Remineralization occurs when acid effects are removed and free $\mathrm{Ca}$ and phosphate ions which are present in the saliva penetrate demineralized enamel areas and the mineral component in them grows.

Teeth caries has a multi-factor nature $[7,12]$. Interaction between the dental deposit, ration components and teeth tissues, as well as genetic and ecological factors, make the greatest contribution into teeth caries pathogenesis $[8,15,16]$. Other caries-inducing factors are the salivation quality and quantity, overall health, and extreme impacts on a body. The saliva, chronic systemic diseases, and weak immunity are thought to be basic internal factor which can cause caries evolvement [3, $6,10,11]$. Therefore, search for risk factors which can cause teeth tissues demineralization is an urgent theoretical and practical task $[2,11,19]$.

Our research goal was to assess risks of caries evolvement in teeth solid tissues among adult working population under acclimatization in a hot humid sea climate.

Our research tasks were:

1. To assess working conditions for adult men performing their work tasks dur- ing summer.

2. To assess dental state and mineral saturation of a body among local population.

3. To examine risks of caries evolvement in teeth solid tissues under acclimatization in a hot humid sea climate.

Data and methods. The examined region belonged to the IV climatic type in the I zone $^{1}$.

Our research objects were 2 groups of healthy males aged from 30 to 40 (34.7 \pm 0.6$)$. People from the first group resided permanently in the Central Russian regions ( $\mathrm{n}=15$ people); the second group was made up of local population $(\mathrm{n}=15)$. All the people took part in our research quite voluntarily (they gave their informative consent). Work category and working conditions were assessed as per their hazard degree and danger ${ }^{1}$.

Males from the first group were sent to the examined region to perform their work tasks. They were observed starting from the third acclimatization day in the hottest time of the year, in July.

Health risk, including that of caries evolvement, was determined as per dental state data: enamel resistance to effects exerted by a standard acid solution (ER-test), saliva $\mathrm{pH}$ determination, salivation rate, and saliva mineralizing potential [1], as well as per impacts exerted on mineral metabolism parameters in a body: determination of mineral substances $(\mathrm{Na}, \mathrm{K}, \mathrm{Ca}, \mathrm{P}$, $\mathrm{Mn}$, and $\mathrm{Cl}$ ) concentrations in blood serum [4]. Dental state was examined and blood tests taken twice, at the same moment of time, on an empty stomach, initially, and 20 days after.

${ }^{1}$ SER 2.2.4.3359-16. Sanitary-epidemiologic requirement to physical factors at workplaces / approved by the Order signed by the RF Chief Sanitary Inspector on June 21, 2016 года о. 81. Available at: http://docs.cntd.ru/document/420362948 (20.08.2017). 
We assessed the following meteorological data: ambient temperature (average, minimum, and maximum), air speed and air relative humidity. We also determined environment thermal load index, or ETLindex ${ }^{1}$.

The results were statistically treated with AtteStat software. Validity of discrepancy for independent samplings was determined as per Mann-Whitney

Results and discussion. Working conditions both group had to work in didn't have any discrepancies and belonged to 2.2 hazard category. Work tasks were performed outdoors, working hours were irregular, and there was high psychoemotional stress. Out-of-town workers, as opposed to local population, were staying at a hostel and received their meals at a catering facility. If any work tasks were to be performed outside the permanent deployment territories, people from both groups had individual meals.

Labor hardness was assessed as 3.2 hazard degree, labor intensity, as 3.2 hazard degree. Average daily outdoor temperature reached $27.40 \mathrm{C}$ on several days, and maximum one reached 30.00C. Relative air humidity was beyond standard $(77.3 \pm 2.6 \%)$, sometimes reaching $80.0 \%$ $100.0 \%$. Minimum wind speed amounted to $2.0 \mathrm{~m} / \mathrm{sec}$, maximum one, to $7,0 \mathrm{~m} / \mathrm{sec}$ $(4.3 \pm 0.3 \mathrm{~m} / \mathrm{sec})$. Microclimate as per ETLindex was assessed as 3.1 hazard degree. The final estimation was that working conditions were hazardous (3.3 hazard degree).

Assessment of mineral substances concentration in blood serum in both groups revealed that people who came to work in a hot humid sea climate had mineral substances in their blood serum in concentrations within reference limits. However, on the $23 \mathrm{rd}$ acclimatization day, we determined an authentic decrease in $\mathrm{K}$ and $\mathrm{Na}$ concentrations: on average, by $11.2 \%(p=0.0038)$ and by $5.0 \%(p=0.003)$ correspondingly in all the examined people. And here $\mathrm{Na}$ concentration was lower than the standard. $\mathrm{Cl}$ concentration decreased in $80.0 \%$ people, by $2.2 \%$ $(p=0.0028)$ on average. As per individual parameters, $46.7 \%$ had $\mathrm{K}$ concentrations lower than the standard, and $13.3 \%, \mathrm{Cl} ; \mathrm{Na}$ concentration was lower than the standard in all the examined people. It proved there was a disorder in a body electrolyte balance. Ca concentration didn't change authentically $(p=0.106)$; however, it fell in $53.3 \%$ of the examined people. Initially, it was lower than the standard in $53.3 \%$, and by the end of the ob-servations, in $66.7 \%$. $\mathrm{P}$ concentration, on the contrary, grew within the reference limits $(p=0.0104)$, which was detected in $86.7 \%$. It resulted in changes in $\mathrm{Ca}: \mathrm{P}$ ratio: initially, it was equal to 2.29 units; by the end of the observations, to 1.76 units. Only Mn concentration was within the same limits (0.95 against $0.92 \mu \mathrm{mol} / 1, \mathrm{p}=0.22$ ) (Table 1).

Table 1

Mineral substances concentrations un blood serum of people from both groups $(M \pm m)$

\begin{tabular}{|c|c|c|c|}
\hline \multirow{2}{*}{$\begin{array}{c}\text { Substance }(\mathrm{mol} / \mathrm{l}) \text {, } \\
\text { Reference limits }\end{array}$} & \multicolumn{2}{|c|}{ Examined groups } & \multirow[b]{2}{*}{$p$} \\
\hline & $\begin{array}{c}\text { Local } \\
\text { popula-tion }\end{array}$ & $\begin{array}{c}\text { Group 1 } \\
\text { (23-rd day) }\end{array}$ & \\
\hline $\mathrm{K}, 3,5-5,1$ & $4,04 \pm 0,08$ & $3,56 \pm 0,15$ & 0,0186 \\
\hline $\mathrm{Na}, 136-146$ & $\begin{array}{c}135,45 \pm \\
0,58\end{array}$ & $\begin{array}{c}128,5 \pm \\
1,33\end{array}$ & 0,0001 \\
\hline $\mathrm{Cl}, 97-107$ & $\begin{array}{c}104,26 \pm \\
1,04\end{array}$ & $\begin{array}{c}100,0 \pm \\
1,17\end{array}$ & 0,0137 \\
\hline $\mathrm{Ca}, 2,15-2,57$ & $2,12 \pm 0,02$ & $2,04 \pm 0,06$ & 0,076 \\
\hline $\mathrm{P}, 0,87-1,45$ & $0,93 \pm 0,03$ & $1,16 \pm 0,08$ & 0,0044 \\
\hline Mn, $0,80-1,00$ & $0,88 \pm 0,05$ & $0,95 \pm 0,05$ & 0,153 \\
\hline
\end{tabular}

All the assessed parameters, Ca excluded, were within the reference limits in local population. However, $40.0 \%$ had $\mathrm{Na}$ concentration lower than the standard; $6.7 \%, \mathrm{~K}$ and $\mathrm{P}$ concentrations; 26.7\%, Mn 
concentrations. Insufficient $\mathrm{K}$ concentrations parameters were the most significant: they were lower than the reference limits in $70.0 \%$ of the examined people which determined average value in the whole group.

Thermal load resulted in $\mathrm{K}$ concentrations (by 11.9\%), $\mathrm{Na}$ concentrations (by $5.1 \%$ ), and $\mathrm{Cl}$ concentrations (by $4.1 \%$ ) being authentically lower in people under acclimatization than in local population, and $\mathrm{P}$ concentration in them was by $24.7 \%$ higher. $\mathrm{Ca}$ and $\mathrm{Mn}$ concentrations didn't have any discrepancies.

We assessed dental state under acclimatization and revealed that saliva $\mathrm{pH}$ was shifting towards acidity with a $8.1 \%$ decrease $(p=0.0022)$ up to $6.66 \pm 0.08$ units. And changes in saliva $\mathrm{pH}$ were detected in $86.7 \%$ of the examined people. $\mathrm{pH}$ was lower than 6.5 units (average standard value), namely 6.2 units, in $20.0 \%$ of them [1]. Saliva $\mathrm{pH}$ in local population didn't have any authentic discrepancies with the same parameter in group 1 as also $20.0 \%$ had it lower than the average standard value (table 2).

Saliva mineralizing potential (SMP) also decreased authentically by $7.1 \%$ $(p=0.0014)$ to $2.6 \pm 0.18$ scores. Initially, it was estimated as satisfactory; by the end of the observations, it was estimated as low in $40.0 \%$ of the examined people. $26.7 \%$ of the local inhabitants had low SMP, and $6.7 \%$, high SMP. Average SMP values in both groups didn't have any authentic discrepancies.

Salivation rate also decreased authentically, by $5.5 \% \quad(p=0.007)$ to $23.92 \pm 1.36$ $\mathrm{ml} /$ hour. It was detected in $86.7 \%$ people. Average parameters in local population didn't have any authentic discrepancies.

We detected a 33.3\% decrease in enamel resistance as per ER-test, $\mathrm{p}=0.0017$ (the parameter grew to $5.1 \pm 0.17$ scores). Initially, it was lower than 3 scores in
$53.3 \%$ which was the evidence that their enamel was substantially resistant to caries; the rest ran some risks of caries evolvement. By the end of the observations, $100.0 \%$ of the examined people ran this risk. ER-test results for local population didn't have any authentic discrepancies with the data obtained in group 1: ER-test showed caries evolvement risk for $80.0 \%$ of them; as for the rest $20.0 \%$, they ran high risk of caries evolvement (Table 2).

Table 2

Dental state characteristics in both groups, $(M \pm m)$

\begin{tabular}{|c|c|c|c|}
\hline \multirow[b]{2}{*}{$\begin{array}{l}\text { Dental state parame- } \\
\text { ters, reference limits }\end{array}$} & \multicolumn{2}{|c|}{ Observation period } & \multirow[b]{2}{*}{$p$} \\
\hline & $\begin{array}{c}\text { Local } \\
\text { population }\end{array}$ & $\begin{array}{c}\text { Group 1 } \\
\text { (23-rd day) }\end{array}$ & \\
\hline $\begin{array}{l}\text { Saliva } \mathrm{pH}, 6.8-7.4 \\
\text { units }\end{array}$ & $6,61 \pm 0,08$ & $6,66 \pm 0,08$ & 0,352 \\
\hline $\begin{array}{l}\text { Saliva mineralizing } \\
\text { potential, } 1-5 \text { scores }\end{array}$ & $2,8 \pm 0,2$ & $2,6 \pm 0,16$ & 0,272 \\
\hline $\begin{array}{l}\text { Salivation rate, } 18- \\
111,0 \mathrm{ml} / \mathrm{h}\end{array}$ & $\begin{array}{c}25,02 \pm \\
1,22 \\
\end{array}$ & $\begin{array}{c}23,92 \pm \\
1,36 \\
\end{array}$ & 0,236 \\
\hline ER-test, 1-10 scores & $5,1 \pm 0,22$ & $5,1 \pm 0,17$ & 0,5 \\
\hline
\end{tabular}

Conclusions:

1. When people had to undergo acclimatization to hot humid sea climate conditions and simultaneously had to work under hazardous working conditions a disorder occurred in their electrolyte balance which was proved by lower $\mathrm{K}, \mathrm{Na}$, and $\mathrm{Cl}$ concentrations in their blood serum. Electrolyte imbalance was less apparent in local population.

2. $70.0 \%$ of local people had Ca concentration in their blood serum lower than the standard. We also detected a decrease in $\mathrm{Ca}$ concentration and an increase in $\mathrm{P}$ concentration in blood serum of people under acclimatization; and $\mathrm{Ca}: \mathrm{P}$ ratio in them changed until it reached the values detected in local population. These data were the evidence Ca was possibly washed out of a body and it led to higher teeth caries risk.

3. Dynamic observations performed on people who came to work in a hot humid 
sea climate revealed that processes related to teeth solid tissue demineralization occurred in them: saliva $\mathrm{pH}$ shifted towards acidity, saliva mineralizing function weakened, salivation rate fell, and enamel re- sistance deteriorated. Therefore, we can state that activities aimed at primary prevention of caries in teeth solid tissues are truly essential.

\section{References}

1. Alimova Z.A., Kurgul'skij A.G. Kriterii ocenki sostojanija stomato-logicheskogo zdorov'ja sotrudnikov specsluzhb: Metodicheskie rekomendacii [Assessment criteria for assessing dental health of special services staff: Methodological Guidelines]. N. Novgorod, izd-vo NGMA, Publ., 2008, 31 p. (in Russian).

2. Emelina G.V., Grinin V.M., Ivanov P.V., Kuznecov N.K., Zljul'kina L.A. Analiz stomatologicheskoj zabolevaemosti $\mathrm{v}$ vybore metodov i podhodov individual'noj profilaktiki kariesa zubov i zabolevanij parodonta [The analysis of dental disease in the choice of methods and approaches of individual prevention of individual prevention of dental caries and paradont diseases]. Sovremennye problemy nauki i obrazovanija, 2011, no. 2, pp. 9-10 (in Russian).

3. Borisenko L.G. Struktura zabolevaemosti slizistoj obolochki rta sredi naselenija starshih vozrastnyh grupp Respubliki Belarus' [Morbidity structure of mucous tunics diseases in oral cavity among elderly age groups in Belarus]. Studopedija, 2015. Available at: https://studopedia.su/18 158265 metodi-prognozirovaniya-kariesa-zubov-primenenieprogrammi-kariogramma-v-prognozirovanii-kariesa-zubov.html (26.06.2015) (in Russian).

4. Kishkun A.A. Rukovodstvo po laboratornym metodam diagnostiki [Guide on laboratory diagnostics techniques]. Moscow, GJeOTAR-Media, Publ., 2009, 800 p. Available at: http: //www.rosmedlib.ru/book/ISBN5970411728.html (24.08.2017) (in Russian).

5. Hafizov R.G., Azizova D.A., Hafizova F.A., Zaripova Je.M., Zhidko A.K. Sovremennye materialy i metody profilaktiki stomatologicheskih zabolevanij: uchebno-metodicheskoe posobie [Contemporary data and techniques for dental diseases prevention: a manual]. Kazan',

Kazanskij universitet, Publ., 2014, 52 p. Available at: http: //dspace.kpfu.ru/xmlui/handle/net/21514 (22.08.2017) (in Russian).

6. Anil S., Anand P.S. Early Childhood Caries: Prevalence, Risk Factors, and Prevention. Front. Pediatr, 2017, no. 5, pp. 157. DOI: 10.3389/fped.2017.00157.

7. Bowen WH. Do we need to be concerned about dental caries in the coming millennium? Crit. Rev. Oral. Biol. Med., 2002, vol. 13, no. 2, pp. 126-131.

8. Brambilla E., Garcia-Godoy F., Strohmenger L. Principles of diagnosis and treatment in high-caries-risk subjects. Dent. Clin. North Am, 2000, vol. 44, pp. 507-540.

9. Sälzer S., Alkilzy M., Slot D.E., Dörfer C.E., Schmoeckel J., Splieth C.H.; Chairs of Working Group 3; ORCA. Socio-behavioural aspects in the prevention and control of dental caries and periodontal diseases at an individual and population level. J. Clin. Periodontol., 2017, vol. 44, no. 18, pp. S106-S115.

10. Cummins D. Dental caries: a disease that remains an urgent public health and health problem in the 21 st century. The exploration of a breakthrough technology for caries prevention. Journal of Clinical Dentistry, 2013, vol. 24, Spec Iss. A, pp. A1-14.

11. Cummins D. The impact of research and development on the prevention of oral diseases in children and adolescents: an industry perspective. Pediatr. Dent., 2006, vol. 28, pp. 118-127.

12. Cummins D., Bowen WH. Biotechnology in oral care. Cosmetic Science and Technology Series. In: R. Lad, ed. New York, Taylor and Francis Ltd, 2006, vol. 29, Biotech in Personal Care, pp. 323-352. 
13. Hayes M.J., Cheng B., Musolino R., Rogers A.A. Dietary analysis and nutritional counselling for caries prevention in dental practise: a pilot study. Aust. Dent. J., 2017, vol. 64, no. 4, pp. 485-492. DOI: 10.1111/adj.12524.

14. Featherstone J.D. Caries prevention and reversal based on the caries balance. Pediatr. Dent., 2006, vol. 28, pp. 128-132.

15. Fejerskov O. Changing paradigms in concepts on dental caries: consequences for oral health care. Caries. Res., 2004, vol. 38, pp. 182-191.

16. Marsh P.D., Percival R.S. The oral microfl ora friend or foe? Can we decide? Int. Dent. J., 2006, vol. 56, no. 1, pp. 233-239.

17. Jepsen S., Blanco J., Buchalla W., Carvalho J.C., Dietrich T., Dörfer C., Eaton K.A., Figuero E., Frencken J.E., Graziani F. Prevention and control of dental caries and periodontal diseases at individual and population level: consensus report of group 3 of joint EFP/ORCA workshop on the boundaries between caries and periodontal diseases. J. Clin. Periodontol., 2017, vol. 44, no. 18, pp. S85-S93.

18. Jørgensen M.R., Castiblanco G., Twetman S., Keller M.K. Prevention of caries with probiotic bacteria during early childhood. Promising but inconsistent findings. Am. J. Dent., 2016, vol. 29, no. 3, pp. 127-131.

19. Reynolds E.C. Calcium phosphate-based remineralization systems: scientific evidence? Issue Australian Dental Journal, 2008, vol. 53, no. 3, pp. 268-273.

Rakhmanov R.S., Alikberov M.Kh., Omarova Z.A. Factors causing risks of caries evolvement in dental solid tissues under acclimatization. Health Risk Analysis, 2017, no. 4, pp. 91-96. DOI: 10.21668/health.risk/2017.4.10.eng

Received: 29.09.2017

Accepted: 18.12.2017

Published: 30.12.2017 